\title{
Evaluation of Age Hardening Behavior Using Composite Rule and Microstructure Observation in Al-Si-Mg Alloy Castings
}

\author{
Mitsuaki Furui ${ }^{1}$, Tomoyuki Kitamura ${ }^{2, *}$, Tatsuya Ishikawa ${ }^{2, *}$, \\ Susumu Ikeno ${ }^{1}$, Seiji Saikawa ${ }^{3}$ and Nobuyuki Sakai ${ }^{3}$ \\ ${ }^{1}$ Graduate School of Science and Engineering for Research, University of Toyama, Toyama 930-8555, Japan \\ ${ }^{2}$ Graduate School of Science and Engineering for Education, University of Toyama, Toyama 930-8555, Japan \\ ${ }^{3}$ Ahresty Corporation, Toyohashi 441-3114, Japan
}

\begin{abstract}
Al-Si hypoeutectic alloys have excellent castability and sufficient strength in combination with other alloying elements. Especially, Al-Si alloy containing $\mathrm{Mg}$ used for high-quality die-casting is well-known as a high strength alloy brought by the appropriate heat treatment and consequential precipitation hardening of $\mathrm{Mg}_{2} \mathrm{Si}$ intermediate phase. T6-heat treatment must be applied for maximum strength, but solution at high temperature and quenching treatment often conduct the product deformation and extra cost for fabrication. Therefore only artificial aging (T5-heat treatment) at comparatively lower temperature is mainly applied to industrial die-casting products. However, there are few studies on age hardening characteristics supplied by T5-heat treatment to Al-Si hypoeutectic alloys. To understand the age hardening behavior of Al10 mass $\% \mathrm{Si}-0.5$ mass $\% \mathrm{Mg}$ and $\mathrm{Al}-10$ mass $\% \mathrm{Si}-0.8$ mass\% $\mathrm{Mg}$ alloys in detail, microstructure observation and hardness measurement were performed. These alloys quenched in iced water, naturally aged at room temperature and artificially aged at 423-523 K, showed conspicuously age hardening behavior. Age hardening of Al-Si-Mg alloy generally considered to be the main cause of the precipitation-based hardening in $\alpha$ phase, nevertheless it was seen that precipitation occurred in $\alpha-\mathrm{Al}+\mathrm{Si}$ eutectic phase. Consequently, from the microstructure observation using SEM, it's thought that the age hardening of these alloys was mainly composed of the hardness change in $\alpha-\mathrm{Al}+\mathrm{Si}$ eutectic phase.

[doi:10.2320/matertrans.MB201010]
\end{abstract}

(Received September 13, 2010; Accepted February 21, 2011; Published April 27, 2011)

Keywords: aluminum-silicon-magnesium alloy casting, age hardening behavior, composite rule, $\alpha$-aluminum + silicon eutectic phase

\section{Introduction}

The basic composition of aluminum based alloys for casting and die-casting is Al-Si systems. Also, the multicomponent system alloys that contain a small amount of $\mathrm{Cu}$, $\mathrm{Mg}, \mathrm{Zn}$ and $\mathrm{Ni}$, etc., are used as a material for cast metal. These Al-Si system alloys have an excellent balance of mechanical properties and castability compared with Al-Mn and $\mathrm{Al}-\mathrm{Cu}$ system alloys, etc. It is usually used in the Al-Si$\mathrm{Mg}$ alloy to make enough mechanical properties that appear with T6 condition by the solution heat treatment and the artificial aging treatment. ${ }^{1)}$ In $\mathrm{Al}-\mathrm{Si}-\mathrm{Mg}$ system alloys for a high-quality die-casting, a solution treatment at high temperature such as T6 heat treatment has been avoided industrially because of problems concerning the manufacturing cost and the deformation by quenching strain. Instead, T5 heat treatment of the artificial aging at comparatively lower temperature has mainly been performed. Regarding global environmental concerns, further improvement of the T5 heat treatment condition is needed for fabricating the high quality die-casting parts from social demand including the automotive light-weightening to reduce the $\mathrm{CO}_{2}$ emission. ${ }^{2,3)}$

In the present study, an Al-10 mass\% Si hypoeutectic alloy containing a small amount of $\mathrm{Mg}$ was cast into a copper made mold with the Y-shaped cavity. Al-10 mass\%Si hypoeutectic alloy is the base composition of ADC12 aluminum alloy which is standardized and widely used in the aluminum diecast industry. This paper will report on the influence of microstructure and age hardening characteristics when the aging treatment is performed under the various temperatures and the $\mathrm{Mg}$ contents.

\section{Experimental Procedure}

\subsection{Material}

The target composition of casting is $\mathrm{Al}-10$ mass $\% \mathrm{Si}$ 0.5 mass $\% \mathrm{Mg}$ and $\mathrm{Al}-10$ mass $\% \mathrm{Si}-0.8$ mass $\% \mathrm{Mg}$ alloys. The $\mathrm{Mg}_{2} \mathrm{Si}$ equivalent is about 0.8 mass $\%$ in 0.5 mass $\% \mathrm{Mg}$ containing alloy and about 1.3 mass $\%$ in 0.8 mass $\% \mathrm{Mg}$ containing alloy. Al-20 mass\%Si alloy, pure $\mathrm{Mg}$ and pure $\mathrm{Al}$ with industrial purity were used for the ingot fabrication, and the alloys were weighed so that the total was $2 \mathrm{kgf}$.

\subsection{Casting procedure}

The copper mold with the Y-shaped cavity was prepared as shown in Fig. 1. Boron nitride was spread on the inside surface of the mold as mold wash. The temperatures of the mold and the center part of the casting were measured by alumel-chromel thermocouple with the diameter of $0.2 \mathrm{~mm}$. Based on the target composition, measured ingots were put into a graphite crucible, and were melted at $993 \mathrm{~K}$ using the electric furnace. After the melting, pure $\mathrm{Mg}$ was added to the
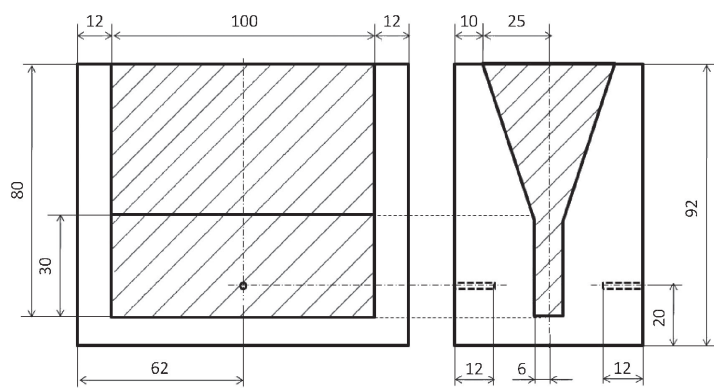

Fig. 1 Dimension of copper mold with Y-block cavity shape. 
Table 1 Chemical composition in mass\% of Al-10 mass $\% \mathrm{Si}-\mathrm{Mg}$ alloy castings used.

\begin{tabular}{cccccccr}
\hline & $\mathrm{Si}$ & $\mathrm{Mg}$ & $\mathrm{Zn}$ & $\mathrm{Fe}$ & $\mathrm{Mn}$ & $\mathrm{Ti}$ & $\mathrm{Al}$ \\
\hline $\mathrm{Al}-10 \% \mathrm{Si}-0.5 \% \mathrm{Mg}$ & 9.94 & 0.51 & $<0.01$ & 0.16 & $<0.01$ & 0.01 & bal. \\
\hline Al-10\%Si-0.8\%Mg & 9.81 & 0.87 & $<0.01$ & 0.16 & $<0.01$ & 0.01 & bal.
\end{tabular}

molten metal. Pouring began when the temperatures of molten metal and mold were dropped to $953 \mathrm{~K}$ and $433-$ $443 \mathrm{~K}$ respectively. After the pouring, the casting was released from the mold for $10 \mathrm{~s}$ when the temperature of casting dropped to $773 \mathrm{~K}$. Immediately after that, the casting was then water-quenched at $273 \mathrm{~K}$ for $10 \mathrm{~s}$. The dimension of casting obtained was $100 \mathrm{~mm}$ length, $12 \mathrm{~mm}$ width and $30 \mathrm{~mm}$ height in the sample part. The chemical composition of casting used in this investigation is listed in Table 1. Si and $\mathrm{Mg}$, the main alloying elements, have been added as a target composition. The cooling rate during the solidification was measured by $\mathrm{C} \alpha$ method $^{4)}$ using the alumel-chromel thermocouple with the $0.2 \mathrm{~mm}$ diameter inserted into the sample part of casting. Cooling rate in 0.5 mass $\% \mathrm{Mg}$ and 0.8 mass $\% \mathrm{Mg}$ containing alloys is $12.5 \mathrm{~K} / \mathrm{s}$. The plate sample with the dimension of $10 \mathrm{~mm}$ width, $12 \mathrm{~mm}$ height and $2 \mathrm{~mm}$ thickness was cut from the sample part of casting.

\subsection{Aging treatment}

According to the process of the T5 treatment that is being adopted in an industrial field, the samples were naturally aged at room temperature for $172.8 \mathrm{ks}$ before they were heated for three artificial aging temperatures at $423 \mathrm{~K}, 473 \mathrm{~K}$ and $523 \mathrm{~K}$ for various durations until $1920 \mathrm{ks}$. After the aging heat treatment, the samples were air-cooled.

\subsection{Hardness measurement}

The plate sample surface was mechanically polished by emery papers with grit numbers from \#500 to \#1200 using water as the lubricant. The ground samples were then buffed using a diamond paste with a diameter of $1 \mu \mathrm{m}$. Vickers hardness was measured by a micro hardness test machine under an indentation load of $4.9 \mathrm{~N}$ and a time of $20 \mathrm{~s}$. Each primary $\alpha-\mathrm{Al}$ and $\alpha-\mathrm{Al}+\mathrm{Si}$ eutectic phases were separately measured under the load of $0.098 \mathrm{~N}$. In particular, primary $\alpha$ $\mathrm{Al}$ and $\alpha-\mathrm{Al}+\mathrm{Si}$ eutectic phases were accurately indented with unaffecting condition from another indentation.

\subsection{Microstructure observation}

The aged sample with specular surface was applied to metallographic observation. Following the polishing operation, the etching of polished sample was done using 1 mass $\%$ hydrofluoric acid aqueous solution. The microstructure was observed using an optical microscope (OM). The volume fractions of $\alpha-\mathrm{Al}$ and $\alpha-\mathrm{Al}+\mathrm{Si}$ eutectic phases were measured from the microstructures by the image processing software installed in the personal computer. In addition to the foregoing microstructure observation, the sample was mechanically ground using the diamond paste. After the polishing operation, microstructure observation in high magnification and elementary analysis were carried out using the scanning electron microscope (SEM).

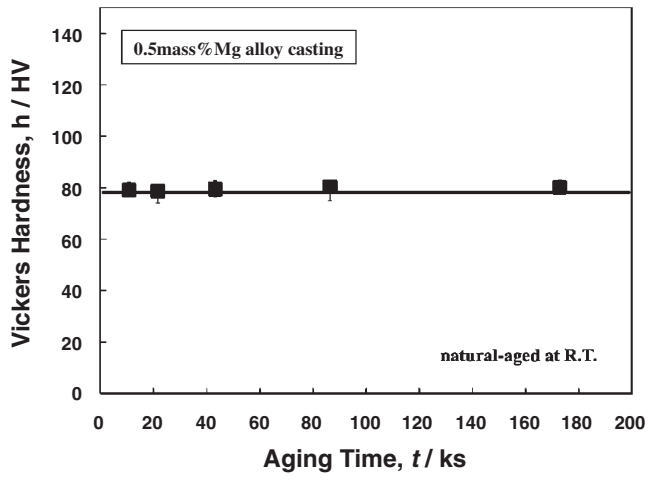

Fig. 2 Hardness variations against natural aging time in Al-10 mass\%Si0.5 mass $\% \mathrm{Mg}$ alloy casting.

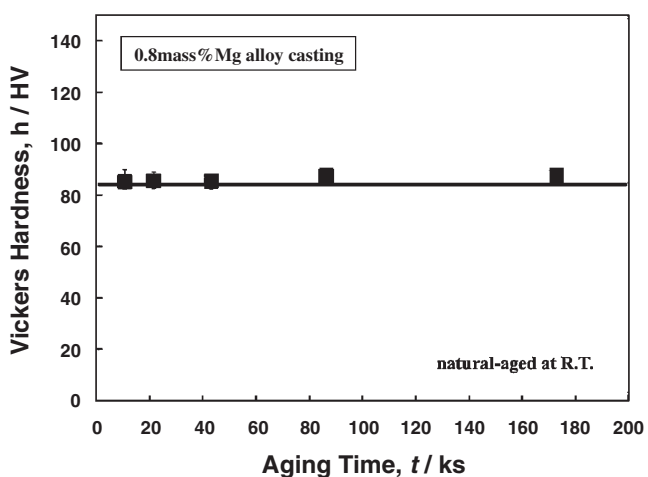

Fig. 3 Hardness variations against natural aging time in $\mathrm{Al}-10$ mass\%Si0.8 mass $\% \mathrm{Mg}$ alloy casting.

\section{Result and Discussion}

\subsection{Age hardening}

Figures 2 and 3 show the hardness variation in natural aging condition of $\mathrm{Al}-10 \% \mathrm{Si}-0.5 \% \mathrm{Mg}$ and $\mathrm{Al}-10 \% \mathrm{Si}-$ $0.8 \% \mathrm{Mg}$ alloy castings. According to these results, age hardening that originated in the natural aging was not able to be confirmed clearly. Therefore, it can be said that the influence of the natural aging on age hardening is extremely low. If under-aging at low temperature proceeds in the alloy system that hardens by the precipitation of $\mathrm{Mg}_{2} \mathrm{Si}$ phase, a negative effect in two-stage aging behavior ${ }^{5,6)}$ seems to appear in $\mathrm{Al}-10 \% \mathrm{Si}-0.5 \% \mathrm{Mg}$ alloy casting. In $\mathrm{Al}-\mathrm{Si}-\mathrm{Mg}$ system alloys, the influence of cooling rate during solidification, aging treatment condition and alloy composition on the positive and negative effects of two-step aging has to be examined in the near future.

The isothermal age hardening curve of $\mathrm{Al}-10 \% \mathrm{Si}-0.5 \% \mathrm{Mg}$ alloy castings aged at $423 \mathrm{~K}, 473 \mathrm{~K}$ and $523 \mathrm{~K}$ is shown in Fig. 4. The aging peak hardness and the time to reach it increases with decreasing aging temperature. Its aging behavior corresponds to the typical aging temperature dependence in age hardenable materials.

In the case of $\mathrm{Al}-10 \% \mathrm{Si}-0.8 \% \mathrm{Mg}$ alloy casting as shown in Fig. 5, the aging behavior was similar to the case of Al$10 \% \mathrm{Si}-0.5 \% \mathrm{Mg}$ alloy casting. As-solution treated hardness of 0.8 mass $\% \mathrm{Mg}$ containing alloy casting is about $7 \mathrm{HV}$ higher than that of 0.5 mass $\% \mathrm{Mg}$ containing alloy casting. 


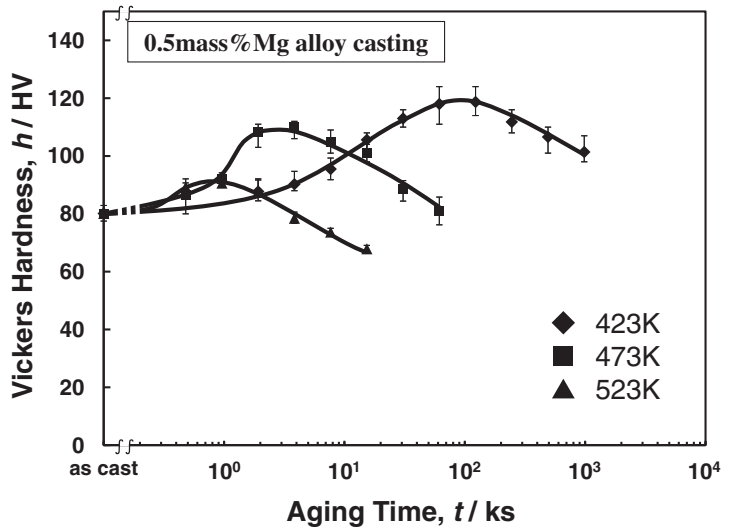

Fig. 4 Isothermal age hardening curves of Al- 10 mass $\% \mathrm{Si}-0.5$ mass $\% \mathrm{Mg}$ alloy casting aged at $423 \mathrm{~K}, 473 \mathrm{~K}$ and $523 \mathrm{~K}$.

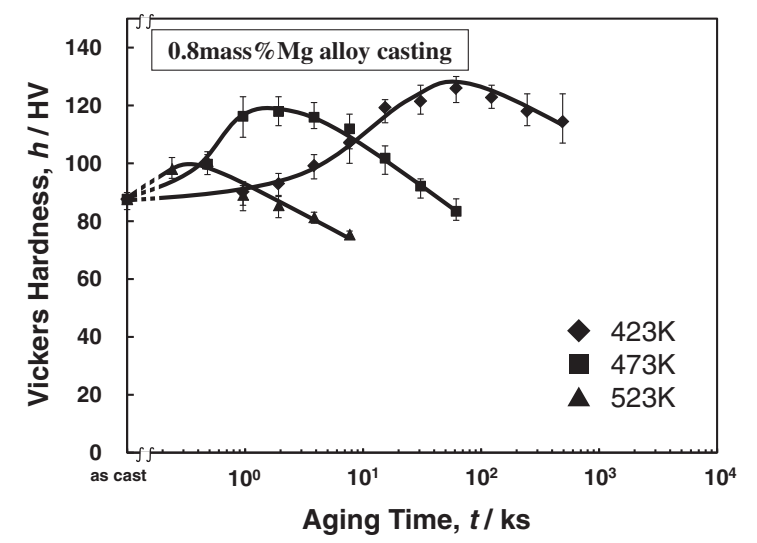

Fig. 5 Isothermal age hardening curves of Al-10 mass $\% \mathrm{Si}-0.8$ mass $\% \mathrm{Mg}$ alloy casting aged at $423 \mathrm{~K}, 473 \mathrm{~K}$ and $523 \mathrm{~K}$.

Also, the time to peak hardness gets shorter at all aging temperatures, and the hardness of $\mathrm{Al}-10 \% \mathrm{Si}-0.8 \% \mathrm{Mg}$ alloy casting is larger than that of $\mathrm{Al}-10 \% \mathrm{Si}-0.5 \% \mathrm{Mg}$ alloy casting in all aging temperatures. M. Tsukuda ${ }^{7)}$ et al. reported that the strengthening of Al-7 mass \% Si alloy under T6 treatment occurred with the $\mathrm{Mg}$ addition up to 0.7 mass\%. It is thought that the reason for difference of age hardening behavior in 0.5 mass $\% \mathrm{Mg}$ and 0.8 mass $\% \mathrm{Mg}$ containing alloys, the age precipitation hardening is promoted with the increasing of $\mathrm{Mg}$ content. M. Kitada ${ }^{8)}$ and C. R. Barrett ${ }^{9)}$ said that the addition of $\mathrm{Mg}$ to $\mathrm{Al}-\mathrm{Si}$ alloy induced the increasing of nucleation speed through the artificial aging.

\subsection{Microstructure}

To examine the age hardening behavior in Fig. 4 and Fig. 5, the phase constituent was observed by OM and SEM equipped with energy dispersive X-ray spectroscopy (EDX). Optical micrograph, secondary electron image from SEM, and elemental mapping from EDX in Al-10 mass\%Si0.8 mass $\% \mathrm{Mg}$ alloy casting are shown in Fig. 6. Figure 6(a) shows that $\alpha$-Al phase occurred as a primary crystal takes on the dendritic form in hypoeutectic composition. $\alpha-\mathrm{Al}+\mathrm{Si}$ eutectic phase occurs in the clearance between $\alpha$-Al phases. As-cast structure consisting of two phases is the typical characteristic in Al-Si alloy with hypoeutectic composition.
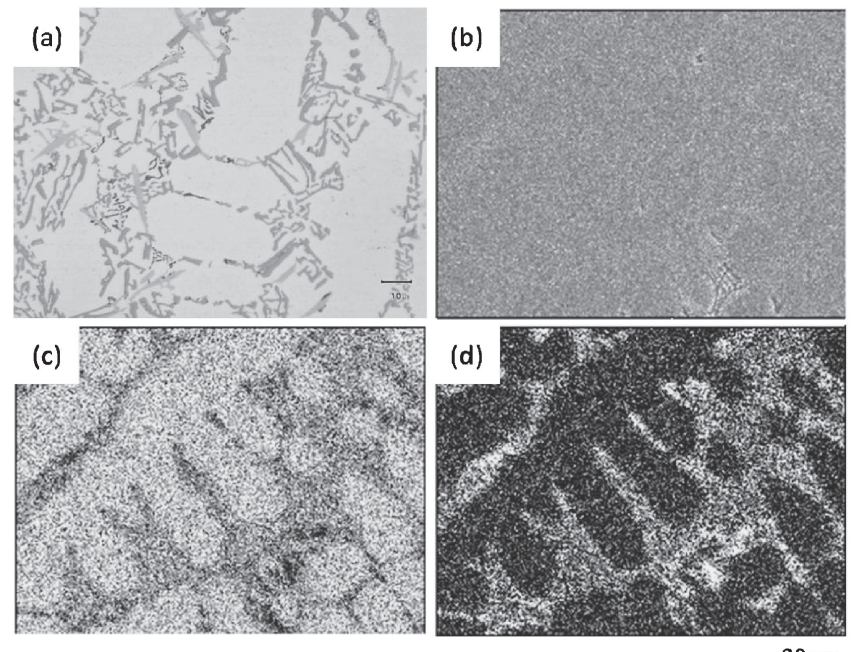

$20 \mu \mathrm{m}$

Fig. 6 (a) Optical microstructure, (b) secondary electron image and, (c) and (d) elemental mapping of $\mathrm{Al}$ and $\mathrm{Si}$ in $\mathrm{Al}-10$ mass $\% \mathrm{Si}-0.8$ mass $\% \mathrm{Mg}$ alloy casting.

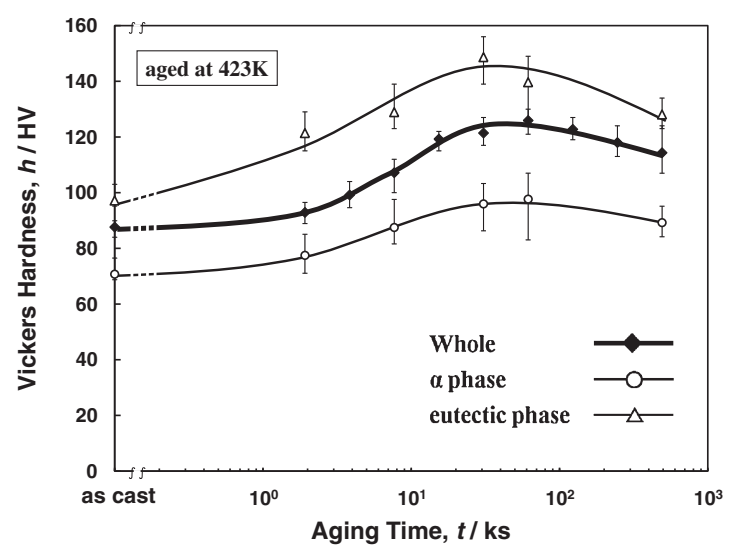

Fig. 7 Variation of Vickers hardness for structure phases of $\alpha$-Al and $\alpha$ $\mathrm{Al}+\mathrm{Si}$ eutectic in $\mathrm{Al}-10$ mass $\% \mathrm{Si}-0.8 \mathrm{mass} \% \mathrm{Mg}$ alloy casting isothermalaged at $423 \mathrm{~K}$.

\subsection{Composite rule}

To examine the dependence of $\alpha-\mathrm{Al}$ and $\alpha-\mathrm{Al}+\mathrm{Si}$ eutectic phases on the aging behavior, each hardness in these phases was measured separately against the aging time. Figure 7 shows the variation of Vickers hardness for structure phases of $\alpha-\mathrm{Al}$ and $\alpha-\mathrm{Al}+\mathrm{Si}$ eutectic in $\mathrm{Al}-10$ mass $\% \mathrm{Si}-$ $0.8 \mathrm{mass} \% \mathrm{Mg}$ alloy castings isothermal-aged at $423 \mathrm{~K}$. Hardness of $\alpha$-Al phase is lower than that of average hardness in the sample, but the hardness variation of $\alpha$-Al phase with aging time has the same tendency as that of average in the sample. Solid solubility of $\mathrm{Mg}_{2} \mathrm{Si}$ to $\alpha$-Al phase in the casting decreases suddenly with temperature drops from 1.85 mass $\%(0.68$ mass $\% \mathrm{Mg}$ and 1.16 mass $\% \mathrm{Si})$ at $868 \mathrm{~K}$ of pseudo binary eutectic point. It seems that the hardness occurs through the precipitation of $\mathrm{Mg}_{2} \mathrm{Si}$ phase with the aging treatment. On the other hand, variation of $\alpha$ $\mathrm{Al}+\mathrm{Si}$ eutectic phase with aging time has the same tendency as that of average hardness in the sample. Age hardening in $\alpha$-Al phase defined as the subtraction hardness from the condition of peak-aged to as-cast is $20 \mathrm{HV}$, which is the small 


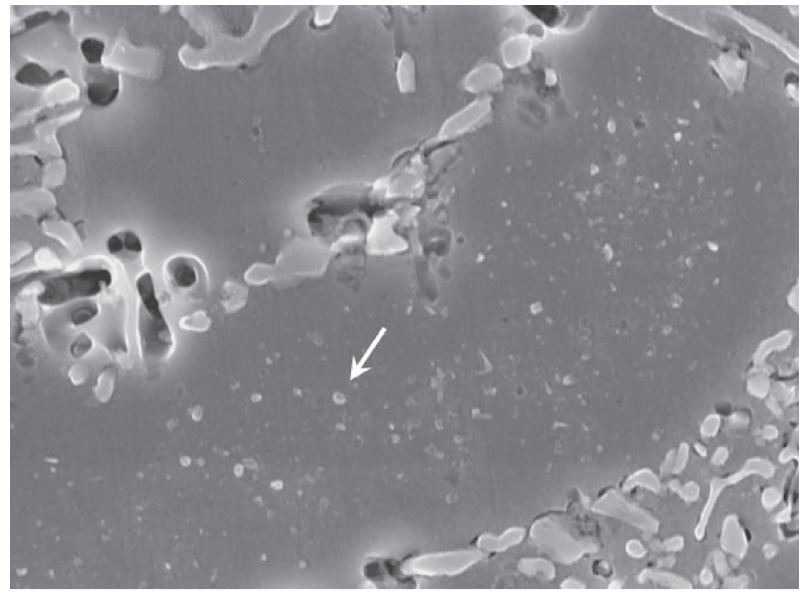

$5 \mu \mathrm{m}$

Fig. 8 SEM image of $\alpha$-Al phase in Al-10 mass $\%$ Si- 0.8 mass $\% \mathrm{Mg}$ alloy casting over-aged at $673 \mathrm{~K}$ for $3.6 \mathrm{ks}$.

value, but that in $\alpha-\mathrm{Al}+\mathrm{Si}$ eutectic phase is about $55 \mathrm{HV}$. From this result, it is thought that age hardening in 0.8 mass $\% \mathrm{Mg}$ containing alloy casting mainly depends on the hardness variation in $\alpha-\mathrm{Al}+\mathrm{Si}$ eutectic phase. It is easy to assume that the precipitates in $\alpha$-Al solid solution are $\mathrm{Mg}_{2} \mathrm{Si}$ phase. In fact, there is no precipitate in $\alpha$-Al phase in the condition of $423 \mathrm{~K}$ aging by SEM observation. It seems that the primary cause of hardening is the solid-solution hardening by $\mathrm{Mg}$ and $\mathrm{Si}$ atoms as $\alpha-\mathrm{Al}$ phase. Figure 8 shows the existence of precipitates in $\alpha$-Al phase of $\mathrm{Al}-10$ mass $\% \mathrm{Si}$ $0.8 \mathrm{mass} \% \mathrm{Mg}$ alloy casting over-aged at $673 \mathrm{~K}$ for $3.6 \mathrm{ks}$. The contrast of precipitates indicated by the white arrow was observed. However, the precipitates have not been observed in $\alpha-\mathrm{Al}+\mathrm{Si}$ eutectic phase with aging treatment using $\mathrm{OM}$ and SEM yet. On the other hand, in squeeze-cast and rheocast A356 alloy with the hypoeutectic composition same as Al-10 mass\%Si-Mg alloy used in this study, S. W. Youn et al. ${ }^{10,11)}$ reported that the age hardening response was observed in $\alpha-\mathrm{Al}+\mathrm{Si}$ eutectic phase similarly in $\alpha$-Al phase.

Figure 9 shows the variation of Vickers hardness for structure phases of $\alpha-\mathrm{Al}$ and $\alpha-\mathrm{Al}+\mathrm{Si}$ eutectic in $\mathrm{Al}-$ 10 mass $\% \mathrm{Si}-0.8$ mass $\% \mathrm{Mg}$ alloy castings aged at $473 \mathrm{~K}$. The variations of average hardness and partial hardness in $\alpha$ $\mathrm{Al}$ and $\alpha-\mathrm{Al}+\mathrm{Si}$ eutectic phases with aging time have the same tendency in the case of $423 \mathrm{~K}$ aging as shown in Fig. 7. Maximum hardness of $\alpha-\mathrm{Al}$ phase aged at $423 \mathrm{~K}$ is about $90 \mathrm{HV}$, but that of $\alpha-\mathrm{Al}+\mathrm{Si}$ eutectic phase is about $150 \mathrm{HV}$. There is a large difference between the hardness of structure phases. It is thought that the volume fractions of $\alpha-\mathrm{Al}$ and $\alpha$ $\mathrm{Al}+\mathrm{Si}$ eutectic phases seemed to affect the age hardening behavior, therefore, general composite rule about hardness was applied in this study;

$$
\mathrm{HV}_{\mathrm{cal}}=\mathrm{HV}_{\alpha} \cdot \mathrm{Vf}_{\alpha}+\mathrm{HV}_{\mathrm{e}} \cdot \mathrm{Vf}_{\mathrm{e}}
$$

where $\mathrm{HV}_{\text {cal }}$ is calculated hardness by composite rule, $\mathrm{HV}_{\alpha}$ and $\mathrm{HV}_{\mathrm{e}}$ are measured hardness in $\alpha-\mathrm{Al}$ and $\alpha-\mathrm{Al}+\mathrm{Si}$ eutectic phases, $\mathrm{Vf}_{\alpha}$ and $\mathrm{Vf}_{\mathrm{e}}$ are volume fraction of $\alpha-\mathrm{Al}$ and $\alpha-\mathrm{Al}+\mathrm{Si}$ eutectic phases. Figure 10 shows the calculated hardness based on the composite rule and measured average hardness in $\mathrm{Al}-10$ mass $\% \mathrm{Si}-0.8$ mass $\% \mathrm{Si}$ alloy casting aged at $423 \mathrm{~K}$,

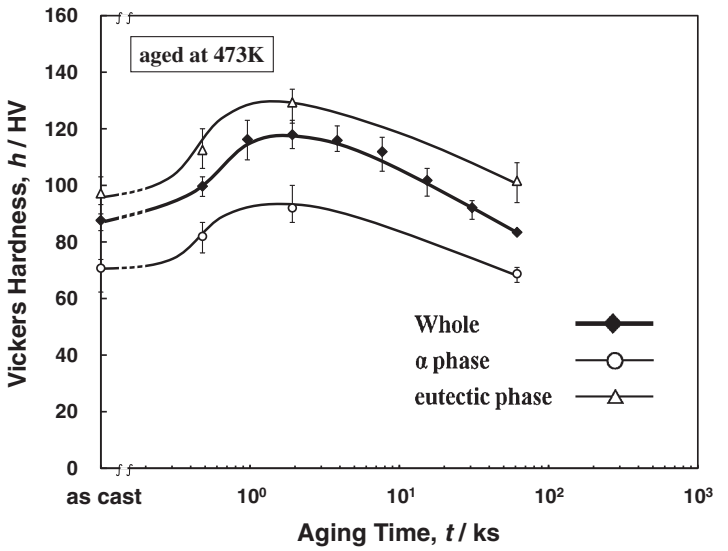

Fig. 9 Variation of Vickers hardness for structure phases of $\alpha$-Al and $\alpha$ $\mathrm{Al}+\mathrm{Si}$ eutectic in $\mathrm{Al}-10$ mass $\% \mathrm{Si}-0.8$ mass $\% \mathrm{Mg}$ alloy casting isothermalaged at $473 \mathrm{~K}$.

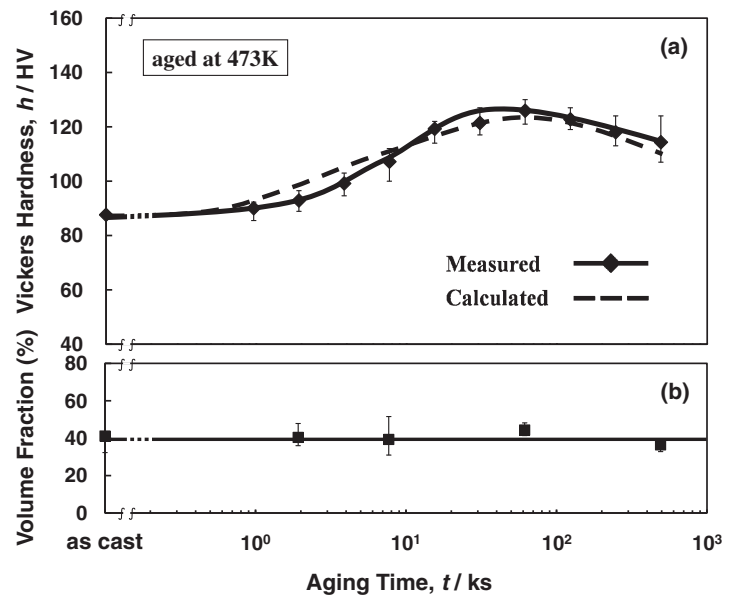

Fig. 10 (a) Comparison between measured and calculated hardness in Al-10 mass\% $\%$ i- 0.8 mass\%Si alloy casting isothermal-aged at $423 \mathrm{~K}$. (b) Relation between volume fraction of $\alpha-\mathrm{Al}+\mathrm{Si}$ eutectic phase and aging time.

in addition to the variation of volume fraction of $\alpha-\mathrm{Al}+\mathrm{Si}$ eutectic phase with aging time. $\alpha-\mathrm{Al}+\mathrm{Si}$ eutectic phase has constant volume fraction of about 0.4 . The hardness of $\alpha$ $\mathrm{Al}+\mathrm{Si}$ eutectic phase was changed remarkably with the aging time, though the volume fraction of $\alpha-\mathrm{Al}+\mathrm{Si}$ eutectic phase had no change. It shows that some reactions contributed to hardening were generated in $\alpha-\mathrm{Al}+\mathrm{Si}$ eutectic phase. Variation of hardness calculated by the composite rule from volume fraction and hardness in $\alpha-\mathrm{Al}$ and $\alpha-\mathrm{Al}+\mathrm{Si}$ eutectic phases with the aging time was similar to that of average hardness measured in the sample. The variation of hardness calculated by the composite rule shown in Fig. 11 was similar to that of average hardness measured in Al10 mass $\%$ Si-0.8 mass $\% \mathrm{Mg}$ alloy casting aged at $473 \mathrm{~K}$.

\section{Conclusion}

Age hardening behavior of Al-10 mass\%Si alloy castings with 0.5 mass $\% \mathrm{Mg}$ and 0.8 mass $\% \mathrm{Mg}$ aged at various temperatures was evaluated from the microstructure observation and the composite rule. From the investigation results, the following conclusions have been obtained. 


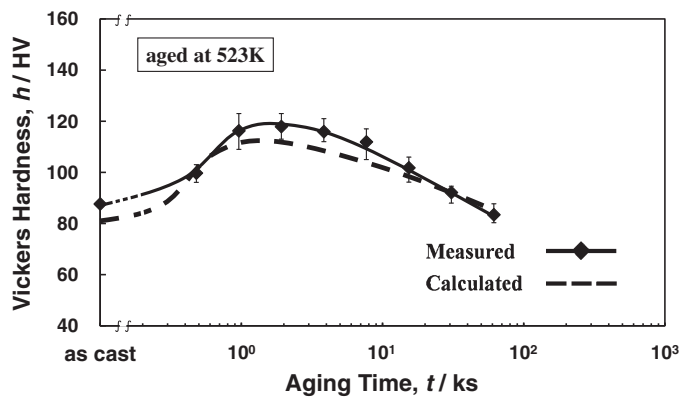

Fig. 11 Comparison between measured and calculated hardness in $\mathrm{Al}$ 10 mass $\%$ Si- 0.8 mass $\%$ Si alloy casting isothermal-aged at $473 \mathrm{~K}$.

(1) Al-10 mass $\% \mathrm{Si}$ alloy casting with 0.5 mass $\% \mathrm{Mg}$ and 0.8 mass $\% \mathrm{Mg}$ obviously showed the age hardening behavior. (2) The age hardening curves calculated from the composite rule in $\mathrm{Al}-10$ mass $\% \mathrm{Si}$ alloy casting with 0.5 mass $\% \mathrm{Mg}$ and 0.8 mass $\% \mathrm{Mg}$ were almost in agreement with those of the measurements, respectively.

(3) Each age hardening of Al-10 mass $\%$ Si alloy casting with 0.5 mass $\% \mathrm{Mg}$ and 0.8 mass $\% \mathrm{Mg}$ were mainly composed of the hardness change in the $\alpha-\mathrm{Al}+\mathrm{Si}$ eutectic phase.

\section{Acknowledgement}

We are grateful to Mr. Daitetsu Aoki and Mr. Kazuhiro Hoshi (Kumagaya Works, Ahresty Corporation) for the chemical analysis of Al-10 mass $\% \mathrm{Si}-\mathrm{Mg}$ system alloy castings.

\section{REFERENCES}

1) N. Nishi: J. JFS 80 (2008) 677-683.

2) D. L. Zhang, L. H. Zheng and D. H. StJohn: J. Light Met. 2 (2002) 27-36.

3) S. B. Hassan and V. S. Aigbodion: J. Alloy. Compd. 486 (2009) 309-314.

4) R. W. Ruddle: The Solidification of Castings, Inst. Metals, (1957).

5) H. Suzuki, M. Kanno and G. Ito: J. JILM 30 (1980) 609-616.

6) M. Murayama and K. Hono: Acta Mater. 47 (1999) 1537-1548.

7) M. Tsukuda, M. Harada, T. Suzuki and S. Koike: J. JILM 28 (1978) 109-115.

8) M. Kitada: Elementary Metal Physics, (AGNE, 1978) pp. 153-158.

9) C. R. Barrett, W. D. Nix and A. S. Tetelman: The Principles of Engineering Materials, (BAIFUKAN, 1980) pp. 115-118.

10) S. W. Youn and C. G. Kang: Mater. Sci. Eng. A 425 (2006) 28-35.

11) S. W. Youn and C. G. Kang: Mater. Chem. Phys. 100 (2006) 117-123. 